\title{
THE PROBLEMATICS OF ASSOCIATION SOUTHEAST ASIA NATION WITHIN HANDLING TRANSNATIONAL CRIME SMUGGLING DRUCK TRAFICKKING
}

\author{
Rendi Prayuda $^{{ }^{*}}$, Tulus Warsito ${ }^{2}$, Surwandono ${ }^{3}$ \\ ${ }^{1}$ Faculty of Social and Political Sciences, Universitas Islam Riau, Indonesia, ${ }^{2,3}$ Doctoral Program of Political Islam, \\ Universitas Muhammadiyah Yogyakarta, Indonesia. \\ Email: ${ }^{1 *}$ prayudarendi904@gmail.com, ${ }^{2}$ tuluswarsito79@gmail.com, ${ }^{3}$ surwandonow@gmail.com
}

Article History: Received on $18^{\text {th }}$ October 2019, Revised on $09^{\text {th }}$ February 2020, Published on $29^{\text {th }}$ February 2020

\begin{abstract}
Purpose of the study: This article describes the transnational crime smuggling druck trafficking smuggling literature, Southeast Asia, with Mauri trading of the BNN exciting routes to be depicted in the Southeast Asian region, more in this article will explain the trade routes and perspectives of countries that produce transit and marketing.

Methodology: The method of research with qualitative descriptive approaches with interviews, documentation of crime action expressed by Southeast Asian communities. First interviews data taken from the UN through a UN organization in the counter Drug and Crime (UNODC), an area that is a regional area in the chain of listings ranging from production, distribution, and consumption of products.

Main Findings: not optimal transnational crime in cases of transnational crime smuggling drug trafficking smuggling in Southeast Asian countries and transnational crime smuggling drug trafficking trades are not on transit routes to the country as transnational crime smuggling drug trafficking markets with indicators of realism, liberalism, and constructivism transnational crime smuggling drug trafficking trade in the Landmark Asia region.
\end{abstract}

Applications of this study: This article contributes theoretically to the development of regional transnational crime smuggling crimes and is a consideration for policymakers in increasing the role of Lot of law enforcement agencies in the Asia Southeast region to make the role of state more optimal.

Novelty/Originality of this study: Researcher in this article found that production countries did not make policy action on the case of transnational crime smuggling druck trafficking in Southeast Asia and the country as transnational crime smuggling drucktrafickking markets were made of cases in the region of West Southeast Asia.

Keywords: Transnational, Treaty, Trade, State, Region, Druck Trafickking.

\section{INTRODUCTION}

This article describes the factors that led to ASEAN's failure to deal with transnational crime in drug trafficking in the Southeast Asia region. Southeast Asia is one of the three producing areas for the manufacture of narcotic extraction. In particular, countries in Southeast Asia are known as the Golden Triangle, which is an area of opium and heroin production located on the border between three countries: Thailand, Myanmar, and Laos which produce $60 \%$ of opium production and heroin in the world. Drug production in the region belongs to the category of narcotics and potential addictive made from the types of opium poppy and papa versomniferum that produce heroin (Fredy, 2002). According to (Bambang,2007) The existence of opium trade in Southeast Asia originated from the Golden Triangle region. The area of the golden triangle is a region located in Southeast Asia consisting of northern Thailand, the western part of Laos, and eastern Myanmar. It is in this area that narcotics, heroin, and amphetamine are produced and distributed all over the world.

Massive smuggling of narcotics poses a big threat to human security in the Southeast Asia region. Therefore, as an ASEAN regional organization, it becomes an important forum for the coordination of member countries in handling illegal drug trafficking. The construction of ASEAN member countries' values and norms is built within the framework of a centralized, independent and neutral model. From 1997 to 2008 the growth of opium in the golden triangle area between Laos, Myanmar and Thailand increased from 4,000 tons in 1990 and up to 9,000 metric tons in 2008. Accelerated narcotics abuse in the Southeast Asia region until 2016 experienced a very significant and dangerous development (UNODC Report. 2016). And data from ASEAN Narco Center that until 2015 the Southeast Asian region became one of the illegal cultivations, manufacturing, and trafficking of narcotics various types of narcotics, the types of marijuana, heroin, opium, amphetamine tablets, ampehatime crystals (ice) are five types that are very familiar circulating in the Southeast Asian region (ASEAN Narco Center. 2016). The establishment of the ASEAN community is supported by the 2015 ASEAN Drug-Free declaration which is basically supported by many parties, especially by member countries. In multilateral organizations such as UN organizations that agree on a forum of anti-narcotics cooperation such as UNODC and countries outside Southeast Asia, it can be said that the commitment contained in this declaration is in line with the intention of the international community (Othman and Idris, 2016).

In ASEAN governance of non-traditional security issues especially on transnational crime issues in accordance with what found that the growing non-traditional security issues affecting relations between nation-states. Puchala explains 
that Thailand is a country in the Southeast Asia region with the highest circulation of narcotics in Southeast Asia. Almost all narcotics are sold and traded in Thailand illegally. Linkages with the ASEAN Region are seen from the advantages and disadvantages as well as other factors on international transactions and regional integration according to Puchala that affect the running of regional integration such as economic, social and political processes (1970). The views of crime in the ASEAN region are experiencing significant developments in international trade, international tourism, and international student exchange. In three cooperative relations between ASEAN countries, Indonesia with Thailand, and Malaysia and other countries are affected by the needs of countries, influenced by language, literature, and education factors in non-ASEAN (Gilligan 2006). The factor of the regime also greatly influences the ASEAN region as it is also influenced by the structure of policymakers, the distribution of political ability with the social, the internalization of the public values, the decision pyramid, the location of decision-making actors and supranational integration (Inglehart 1970). Based on previous studies, so this paper focuses on the factors that led to the failure of the ASEAN security regime to deal with transnational crime in drug trafficking in Southeast Asia through negotiations at the regional level of member countries and supervision of regional collective agreements implemented in each country ASEAN members.

Research Gap FOCUSED ASEAN Problemmatika in dealing with transnational crime trafficking in the Southeast Asian region in the context of the dynamics of transnational crime development and governance OF ASEAN security Rezin and factors that impede in dealing with transnational crimes of narcotics trafficking in the Southeast Asian region.

Research on transnational crime in narcotics smuggling in the Southeast Asia region has not been carried out by many international relations researchers. Therefore the author tries to analyze the failure of the ASEAN security regime in dealing with the transnational crime of drug trafficking in the Southeast Asia region. The presence of Drug-Free ASEAN can be a guideline as well as encourage member countries to take appropriate action related to the handling of drugs at the national or regional level. As a forum for regional cooperation, ASEAN plays a big role in overcoming the phenomenon of the increasingly widespread drug trafficking in South East Asia. Responding to the phenomenon of narcotics smuggling in Southeast Asia, then since the 1970s ASEAN countries began to hold several important diplomatic meetings to anticipate it. ASEAN governance of non-traditional security issues especially on transnational crime issues, ASEAN is still based on the basic principle of ASEAN that is non-intervention and respects the sovereignty of ASEAN countries. So, ASEAN continues to work with member countries in the field of legal politics and security and always carry out the coordination of each country both at the head of state, the Minister and Ambassador of each ASEAN country. Coordination mechanisms undertaken by ASEAN sectoral bodies dealing with the ASEAN Political-Security Community are conducted through diplomatic negotiation mechanisms by establishing the ASEAN Security Community Coordinating Conference (ASCCO).

Objectives of the first study is to explain the development and dynamics of drug circulation crimes and illegal drugs in regional areas, both describing the governance and policy OF ASEAN's security regime in addressing the transnational crimes of narcotics trafficking in the Southeast Asian region, third explaining THE ASEAN regime's inhibitory factors in addressing the transnational crimes of narcotics trafficking in the Southeast Asian region.

\section{.LITERATURE REVIEW}

Some Regional institutions conduct policy responses to regional Crimes (Capie, 2008) with diplomatic UDI (Kaseda, 2012) on policies that review consensus and controversy and some conceptual gaps related to policy That is approaching required literature. In particular, countries in Southeast Asia are known as GoldenTriangle, an area that is liquid opium and heroin production located on the border between three countries, Thailand, Myanmar and Laos which produce $60 \%$ of opium and foreign production in the world. Drug production in the region belongs to the BNN category and the potential for addiction made from Lot opium Poppy and Papaver somniferum that produces heroin. This relates to the development of implications for the persistence strategy and the use of strategy in the context (TOC) and identifies the central issues to fight the Pit TOC in the context of political, professional and academic agenda. The results of this research are Kopassus strategically in law enforcement involving a number of policy actors (Coyne \& Bell, 2011). In the globalization of the transnational Gun culture and masculinity, Kong and the Resistance (Coyne \& Bell, 2011) Transnational crime is also influenced by economic factors, the industrial relations of the drug of the illicit, and the media. As well as the values of social practices and government institutions as well as State policies and cultural education. Model of the international criminal regime in which the regime changed the behavior of the state although it has no law enforcement mechanisms and the International Criminal Tribunal (ICC) which can cause terrible leaders to retain power for longer.

According to ( $\underline{\text { Jo \& Simmons,2016) }}$ that affect is the fault of discipline, rule of law, political type, killing government, and ICC involvement. This is an interconnected history of ASEAN's interaction that ASEAN is not a security community, but if ASEAN's policymakers and their strengthening security community continue to reject realism, they will set aside the most powerful tool for analyzing and managing China's rise, so ASEAN needs to create security communities (Jo \& Simmons, 2016) This is in accordance with (Alter, Hafner-Burton, \& Helfer, 2019), (Groupe de la Banque Mondiale,2017) and (Ferejohn,2002) finding that the development of law enforcement is uneven in international legal judicialization, the International Criminal Court (ICC). Myanmar and heroin also entered Thailand through the Laos border. The skyrocketing production of illegal methamphetamine Myanmar in 1990, followed by the increasingly swift flow of illegal narcotics in the Thai region originating from Myanmar (Friedman,1996). 
The presence of opium trade in Southeast Asia originated from the Golden Triangle region. The area of the golden triangle is a region located in Southeast Asia consisting of northern Thailand, the western part of Laos, and eastern Myanmar. In this area narcotics, heroin and amphetamine are produced and distributed all over the world (McLlroy,1992) The development of narcotics business that has multiplied profits indirectly affects the main actors (Ahmad \& Ghoshal,1999), especially in the Myanmar region is very difficult to conquer. Military rulers in Myanmar even tend to legalize in quotes to narcotics manufacturers in Myanmar, especially the Wa ethnic group, known as the main producer of amphetamine. From this golden triangle area, illegal drugs are then to Thailand. The other route is through Yunan, Guang Dong, Hongkong and Macao in China (Martínez \& Eng,2018). While in other narcotic transit routes in Southeast Asia are Vietnam, Cambodia, and the Philippines. Further from this region, illegal drugs are distributed illegally in Asia including Southeast Asia.

So transnational crime is growing by (Srikanth, 2016) transnational crime in this era of globalization lies in economic, technological and political and is used for terrorist forces and transnational crime networks, (Shiraishi, 2006) a strategy to overcome this by establishing security agencies in India and ASEAN that involve the military, intelligent and policymakers. The authors, therefore, illustrate that the factors affecting the failure of the ASEAN security regime in dealing with transnational crime of smuggling of narcotics in Southeast Asia can be analysed from the two models outlined above ie the negotiation of international or regional regimes and negotiations at the national level in terms of ratification process (Henry,2007)(Jajri \& Ismail,2014) international ASEAN related narcotics smuggling as a transnational engagement that threatens human security. This study focuses on the emphasis on research issues related to shifting issues and concepts of traditional war-related and military security towards non-traditional security in the form of transnational crime activities including narcotics smuggling and accelerating transnational crime very quickly in crime modus operandi and weaknesses of the state and international organizations in overcoming the problem. This can be described as follows:

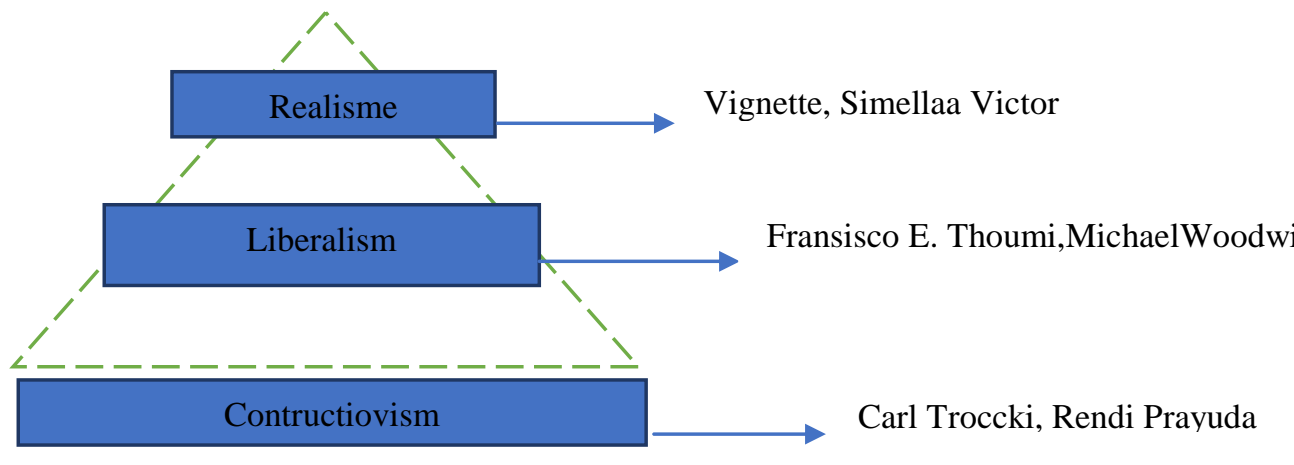

Figure 1: Research Matrix of the ASEAN Perspective in Dealing with Transnational Crime Narcotics Smuggling in Southeast Asia

In this study, the authors use the constructivism perspective, especially in analyzing the factors that affect the ASEAN security regime not yet optimal in dealing with transnational narcotics crime in Southeast Asia. In addition, by definition, the concept of an international regime is an instrument that is shaped by the state and is considered effective to help achieve the interests (Hasenclever, 1997). A regime also believed to be the determinant of where the affairs of state container will be taken, because in its implementation, reviewing the regime of issue-areas in regional or global scale that are more specific based on the principle of self-help Sebuah regime also believed to be the determinant of where the affairs of state container will be taken, because in its implementation, reviewing the regime of issue-areas in regional or global scale that are more specific based on the principle of self-help (Hasenclever, Mayer, 2000). Within the international regime itself, there are three main theories which are considered as perspective-based theoretical approaches namely neo-liberalism, realism, and cognitivism (Hasenclever, 1997).

The study of the motives of the actors in choosing the building of the negotiating regime refers to two major choices. First, the choice to focus more on situational management to support the implementation of the negotiation process between conflicting parties to resolve the issue peacefully. Second, the choice to establish a negotiating regime as a regime that can resolve problems faced by the party - the party of the conflict through building compliance bargaining or getting it done. Therefore, in Bertram I. Spencer and I William Zartman's study, the process of establishing a negotiating regime consists of two major components, namely the negotiation process at the international level and the negotiation process at the national level, namely as follows:

In this study, the authors use the perspective of constructivism (Newman, 2001), especially in analyzing the factors that influence the ASEAN security regime not yet optimal in dealing with transnational narcotics crimes in Southeast Asia. In addition, the definition of the concept is that an international regime is an instrument formed by the state and is considered effective to help achieve interests (Hasenclever, Mayer, 2000), (Sujianto,2018). A regime is also believed to be a place to determine where the affairs of the state will be brought (Jobes, 2003) because, in its implementation, the 
regime examines issues (Kraft, 2017)on a regional or global (Kim, 2014) scale that are more specific based on the principle of self-help (Hasenclever, Mayer, 2000).

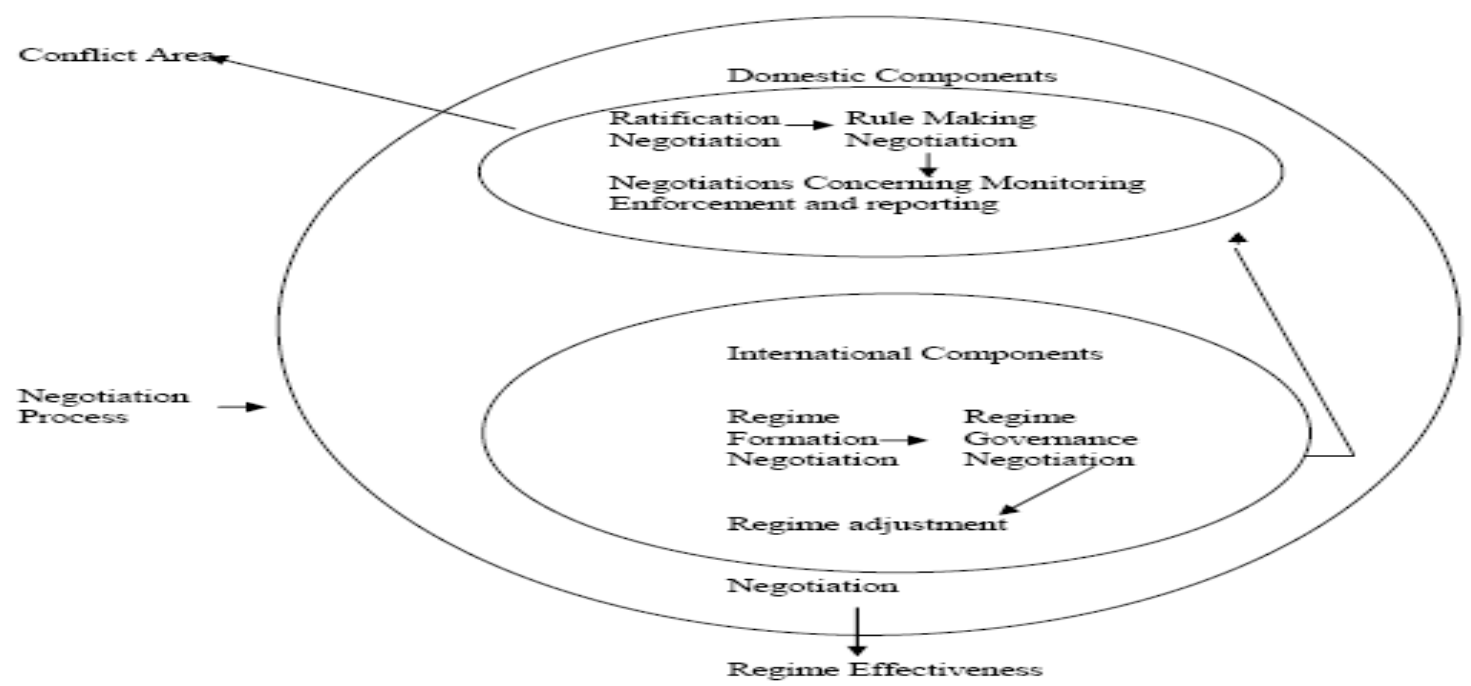

Figure 1: Rezime Dynamics in a Post Agreement Negotiation Framework

Source: Author Data

\section{METHODOLOGY}

Based on the explanation in the background of the problem, the escalation of the development of transnational crime in the Southeast Asian region is growing very rapidly. Even in the case of narcotics smuggling according to data from the United Nations through the United Nations organization on Counter of Drugs and Crime (UNODC), this region is a regional area in the chain of narcotics starting from the production, distribution, and consumption of products. Acceleration of narcotics smuggling transnational crimes in the Southeast Asia region must be anticipated with regional and multilateral cooperation from ASEAN member countries. The implementation of the joint declaration of ASEAN countries in anticipating the circulation of narcotics and illegal drugs in the Southeast Asia region which has been explained in the background of the research above, encourages researchers to formulate research problems in the form of "What factors hinder the ASEAN security regime in dealing with transnational narcotics smuggling crimes in the Southeast Asia region? The research approach used in this research is a qualitative approach. However, this study also uses some quantitative data such as statistical data tables, graphs and quantitative diagrams on the development of the scale of the numbers of an empirical phenomenon.

\section{RESULTS/FINDINGS}

The Southeast Asia region has a very strategic area, especially as a trade and sea transportation route. Therefore, it is not uncommon for the Southeast Asian region to be used as an international illegal narcotics trade route. The following are data on the development of opium growth in the Golden Triangle region according to the UNODC report, namely:

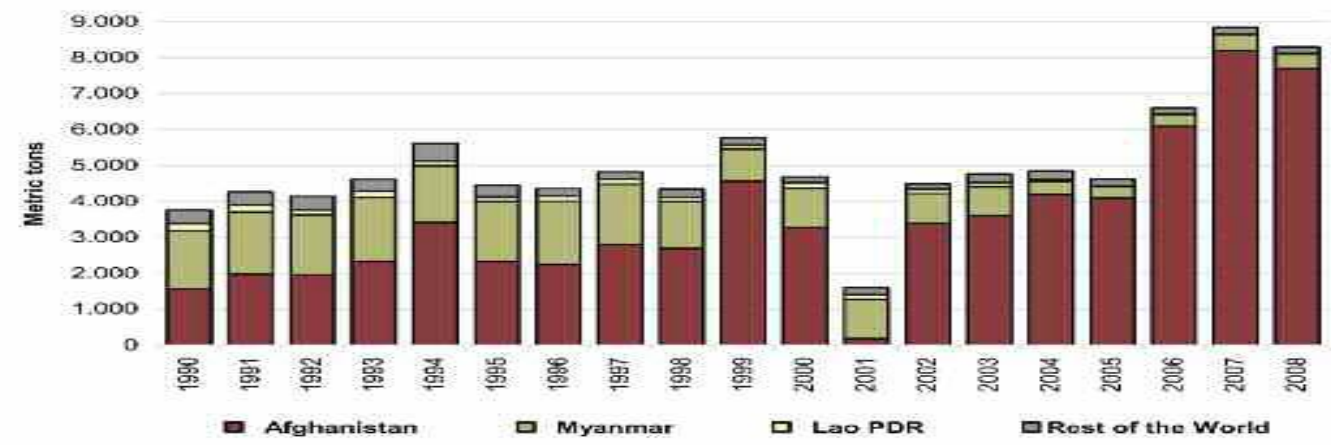

Figure 3: Opium Growth in the Golden Triangle Region (Laos, Myanmar, and Thailand)

Source: Opium cultivation in the Golden Triangle (1998-2007) - UNODC Report.

Based on the graph above, from 1997 to 2008 the growth of opium in the golden triangle area between Laos, Myanmar and Thailand increased from 4,000 tons in 1990 and up to 9,000 metric tons in 2008. Accelerated narcotics abuse in the Asian region of Southeast until 2016 experienced very significant and dangerous development. ASEAN NARCO data explains that until 2015 the Southeast Asian region became one of the illegal cultivations, manufacturing, and trafficking 
of narcotics. Of various types of narcotics, the types of marijuana, heroin, opium, amphetamine tablets, ampehatime crystals (ice) are five types that are very familiar circulating in the Southeast Asian region. The following is a data table on the types of narcotics in the Southeast Asian region, namely as follows:

Table 1: Kinds and Types of Narcotics in the Southeast Asia Region for 2014-2016

\begin{tabular}{|c|c|c|c|c|c|c|}
\hline \multirow{3}{*}{ NO } & \multirow{3}{*}{ States } & \multicolumn{3}{|c|}{ Kinds of Narcotic (\%) } & \multirow{2}{*}{\multicolumn{2}{|c|}{ Methamphetamine }} \\
\hline & & \multirow{2}{*}{ Marijuana } & \multirow{2}{*}{ Heroin } & \multirow{2}{*}{ Opium } & & \\
\hline & & & & & (tablet) & (ice) \\
\hline 1 & Indonesia & 15,1 & 0,2 & 5,0 & 0 & 79,7 \\
\hline 2 & Malaysia & 5,5 & 38,2 & 0 & 4,1 & 52,1 \\
\hline 3 & Singapura & 5,8 & 37,7 & 0,9 & 0 & 55,6 \\
\hline 4 & Filipina & 4,1 & 1,2 & 0 & 0 & 94,8 \\
\hline 5 & $\begin{array}{l}\text { Brunei } \\
\text { Darussalam }\end{array}$ & 2,5 & 4,4 & 0 & 93,1 & 0 \\
\hline 6 & Thailand & 5,8 & 0,5 & 0,2 & 63,9 & 6,0 \\
\hline 7 & Kamboja & \multicolumn{5}{|c|}{ Unable to classified } \\
\hline 8 & Vietnam & 0,7 & 30,1 & 0,7 & 26,2 & 43,0 \\
\hline 9 & Laos & \multicolumn{5}{|c|}{ Unable to classified } \\
\hline 10 & Myanmar & 0,4 & 33,2 & 9,9 & 45,2 & 11,8 \\
\hline
\end{tabular}

Source: ASEAN-NARCO Report. Years of 2015

Based on the table data above, each country in Southeast Asia has a different number of types and types of narcotics. This is of course influenced by domestic demand for illegal narcotics needs. Of the five types of narcotics that are familiar circulating in the Southeast Asia region, the type of methamphetamine in the form of tablets and crystal chunks is the largest type in circulation. Therefore, it can be concluded briefly that the type of methamphetamine in the form of tablets is a ready-made item while those in the form of crystal chunks are a type of narcotics that will be reprocessed for retail or retail sale by extracting it in Indonesia. Illegal drug trafficking and smuggling in the Southeast Asia region does not only come from ASEAN countries but also exported from countries outside Southeast Asia. The following are data on the origins of narcotics circulating in Southeast Asia, namely:

Table 2: Chain of Narcotics Circulation in Southeast Asia 2014-2016

\begin{tabular}{|c|c|c|c|c|c|c|}
\hline \multirow[b]{2}{*}{ NO } & \multirow[b]{2}{*}{ States } & \multicolumn{3}{|c|}{$($ Region/\%) } & \multirow{3}{*}{$\begin{array}{ll}\text { Asia } & \text { dan } \\
\text { Oceania } & \\
\end{array}$} & \multirow[b]{2}{*}{ Eropa } \\
\hline & & ASEAN & Africa & USA & & \\
\hline 1 & Indonesia & \multicolumn{4}{|c|}{ Unable to classified } & \\
\hline 2 & Malaysia & 50,0 & 0 & 50,0 & 0 & 0 \\
\hline 3 & Singapura & \multicolumn{5}{|c|}{ Unable to classified } \\
\hline 4 & Filipina & 0 & 6,9 & 13,8 & 79,3 & 0 \\
\hline 5 & Brunei Darussalam & 100 & 0 & 0 & 0 & 0 \\
\hline 6 & Thailand & 56,3 & 9,4 & 6,3 & 9,4 & 18,8 \\
\hline 7 & Kamboja & 97,8 & 0 & 1,1 & 1,1 & 0 \\
\hline 8 & Vietnam & 57,1 & 0 & 14,3 & 14,3 & 14,3 \\
\hline 9 & Laos & 23,5 & 0 & 0 & 76,5 & 0 \\
\hline 10 & Myanmar & \multicolumn{5}{|c|}{ Unable to classified } \\
\hline
\end{tabular}

Source: ASEAN-NARCO Centre. 2015

Therefore, ASEAN as a regional organization has made various efforts to deal with the threat of narcotics smuggling. Several steps taken by ASEAN in dealing with transnational crime have been carried out since the beginning of 1976 with the agreement of the ASEAN Ministerial Meeting on Transnational Crime (AMMTC), ASEAN Ministerial Meeting on Drugs Matter (AMMDM) and the ASEAN Senior Officials on Drug Matters (ASOD) to arrive at the ASEAN drugfree agreement declaration in 2015. However, until now the efforts made by ASEAN in dealing with a transnational crime have not been optimal, this was accompanied by an increase in transnational criminal activities, especially related to narcotics smuggling in various Southeast Asian countries.

\section{DISCUSSION / ANALYSIS}

The problems faced by the ASEAN security regime can be analyzed from two aspects, namely the negotiation process at the international level and the negotiation process at the national level. Negotiations at the international level refer more to the activities of making negotiation regimes at the ASEAN level which places more emphasis on the interests of 
ASEAN member countries in drafting an ASEAN agreement on the handling of transnational narcotics smuggling crimes. Whereas in the negotiation process at the national level more refers to the ratification activities of products of international law by ASEAN countries in following the results of international legal product agreements in dealing with transnational narcotics smuggling crimes which are used as a framework for law enforcement in ASEAN countries. The following is a chart of transnational crime in the Southeast Asia region, namely:

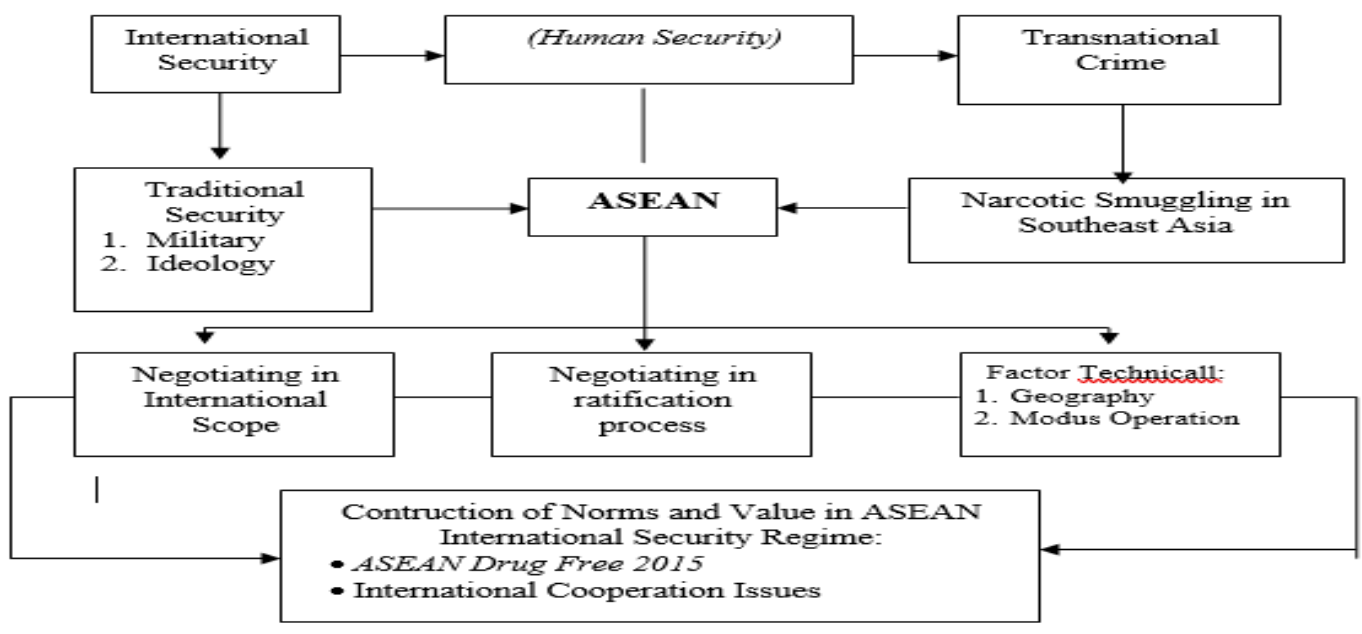

Figure 4: Research Thinking frameworks and analysis flow

Source: Processed Data Research year 2018

Therefore, the description of the problems faced by the ASEAN security regime in dealing with the transnational crime of drug trafficking in the Southeast Asia region is as follows:

\section{The Negotiation Process Factor at the level of the ASEAN Security Regime}

The negotiation process at the level of the ASEAN security regime will be effective if in the process of resolving conflicts or security issues at the ASEAN level it provides broad space for negotiating actors to explore alternatives to problem-solving comprehensively in the process of forming a negotiation regime. In terms of the implementation of negotiations related to handling transnational crime in narcotics smuggling in the Southeast Asia region, the ASEAN security regime has held various methods of mutual agreement and the joint declaration of ASEAN Drug-Free. However, in the negotiation process at this international level, the implementation still faces various obstacles, especially in the process of bargaining and the existence of the ASEAN security regime itself in solving problems of joint security, especially the problem of narcotics smuggling. Some of the inhibiting factors in the effectiveness of the negotiation process at the ASEAN regional level are as follows:

\section{Differences in Perception of ASEAN Countries on the Threat of Narcotics Smuggling in the Southeast Asia Region}

In handling cases of narcotics smuggling in the Southeast Asia region, efforts are needed to equalize the perceptions of ASEAN member countries against the threat of narcotics in the Southeast Asia region by building shared values that narcotics are not only a threat to narcotics production countries such as Indonesia and the Philippines but also threats for countries producing narcotics raw materials such as Myanmar, Laos, and Thailand so that an understanding of these problems was found. The problem of perceptions referred to in this study is in the form of the perspective of leaders in each ASEAN member country in understanding the problem of narcotics, especially related to the abuse and smuggling of narcotics in the Southeast Asia region. On the one hand, all the governments of ASEAN member countries do agree that narcotics is a common threat in the Southeast Asia region so that regional and international cooperation and coordination are needed in anticipating these problems, this is evidenced by the 2015 Declaration of ASEAN Drug-Free joint declaration, however in its implementation, if viewed by using an international regime approach with the viewpoint of liberalism according to Hansclaver, the adherence and adherence of a country to an international regime is based more on problems of the country's interests on issues or agreements discussed in the international regime's agenda, meaning that a country has an interest on the issues discussed in the international regime, it will increasingly make the country comply with and encourage other countries to participate in and comply with an agreement in the international regime.

\section{Differentiation of Priorities of Interest and Agenda of ASEAN Country Leaders}

The differentiation priority of the interests of the leaders of ASEAN countries in this regard is that since ASEAN stood up to the agreement of the ASEAN community which moves in three fields starting from the economy, cultural sociology to the ASEAN political and security community it can be said that the agreement has been agreed but in the implementation still not optimally implemented, especially related to ASEAN political and security community issues. 
This ASEAN political and security community has not been institutionalized properly, this can be described that in various problem-solving in ASEAN, especially related to the phenomenon of transnational crime in Southeast Asia, political leaders in ASEAN countries are still focusing on various challenges in their respective countries. - each member country and does not discuss regional issues. At present, ASEAN leaders are still busy with their respective domestic problems such as President Jokowi, Prime Minister Najib and President Rodrigo Duterte so they do not have the focus to discuss regional issues including the issue of ASEAN community security is no longer the security issue of member countries internal. According to Prime Minister Lee Hsien Long that:

"The domestic agendas must be dealt with, but if it becomes very time consuming and you do not have time to take care of ASEAN cooperation or you cannot make ASEAN cooperation matters as important, for example in terms of investment guarantees, trade, economic cooperation or the problem of human resources and human security, we will have a container but not fully fill the substance" (Mahbubany Kishore and Jeffery. 2017. p. 277).

\title{
Values and Basic Principles of ASEAN Organizations that Have Not to Bind
}

Until now, ASEAN still adheres to its values and principles from the beginning. However, amendments to these values and principles must be adjusted to the changing issues and the polarization of power in countries in the Southeast Asian region or regionally. So that various expert perspectives view ASEAN as emphasizing more attention on the construction of shared values, shared identities and goals, and a sense of belongingness; in other words the internal ideational considerations of the region (Robert O Keohane and Lisa L Martin. 1995. p. 51). In addition, according to the SecretaryGeneral of the ASEAN National Secretariat in Jakarta that:

\begin{abstract}
On the one hand, the values and norms of ASEAN which are very high in the principle of nonintervention, respecting the sovereignty of countries and resolving all problems peacefully have resulted in ASEAN still in existence from 1968 to the present, making ASEAN a loose type of organization. However, along with the times and changes in the polarization of international forces and issues in international politics, ASEAN member countries must begin to internalize ASEAN values into the lives of their member countries so that ASEAN becomes a regional organization that is not merely a ceremonial organization. but is able to make a real contribution to each of its member countries. Therefore, the formation of the ASEAN community is one of the means for ASEAN to internalize the similarities of interests and agendas of each member country. Even though the problems of values and principles of ASEAN have sometimes taken ASEAN hostages to actively participate in resolving issues, especially related to issues of conflict and security in the Asian region Southeast. (The results of the author's interview with the ASEAN National Secretariat Setditjen on July 2, 2018).
\end{abstract}

\section{ASEAN Does Not Have a Natural Guard against the Implementation of Joint Decisions}

The development of increasingly rapid transnational crime and the crisis and deterioration of the electability of the central state in ASEAN organizations has resulted in ASEAN losing its heyday like in the 1980s with the existence of the central political figure of ASEAN countries. Therefore in dealing with transnational narcotics crimes in the Southeast Asia region until now, ASEAN does not have natural guards like other regional organizations. The European Union has remained strong and resilient to date because France and Germany accept joint responsibility to keep the organization alive. Therefore, in its development up to now, the absence of natural guards in ASEAN itself presents a challenge to the existence of ASEAN, especially regarding who is fully responsible for ASEAN organizations.

\section{Sense of Joint Ownership of Southeast Asian Communities towards ASEAN Organizations}

The sense of ownership of ASEAN organizations to date has not been felt to adequately represent all stakeholders in ASEAN. This means that the implementation of ASEAN organizational ownership is still felt mainly by the state government in that area. While its citizens do not have a deep sense of ownership of ASEAN. This is evident in a survey conducted by the ASEAN Foundation about ASEAN awareness in the younger generation. So the results of the study showed that a survey of 2,170 students in ten ASEAN countries, 39\% of respondents answered that they knew little or no knowledge about ASEAN. And on average the respondents only managed to mention nine in the first half of the member countries and only correctly pointed out seven countries on the map. A total of $26 \%$ did not succeed in showing the correct ASEAN flag and related when the date of ASEAN was established. So that this becomes a challenge and a separate problem for ASEAN in dealing with issues of transnational crime, especially related to narcotics smuggling in the Southeast Asia region.

\section{Factors in the Ratification and Law Enforcement Process in each ASEAN Member Country}

Based on the author's observation, on the one hand, it is a threat to the dangers of narcotics, in general, all ASEAN member countries believe that narcotics crimes are a common threat. However, the response of ASEAN countries is still diverse, especially related to the basic regulations for combating narcotics in each country. Therefore, the following is an implementation framework of law enforcement for every country in the Southeast Asia region and problems in evaluating ASEAN values and norms when implemented in each country in dealing with the transnational crime of narcotics smuggling, namely: 


\section{Law Enforcement in Indonesia}

In the face of threats to transnational narcotics crime, Indonesia has made various efforts to anticipate the threat. The policy of the Prevention and Eradication of Drug Abuse and Illicit Circulation (P4GN) is one of the policies made by Indonesia to make its territory free from drugs. This policy was prepared by the National Narcotics Agency (BNN). The problem of monitoring and evaluating ASEAN values and norms in Indonesia occurs in technical problems related to the increasing number of narcotics users and the increased smuggling of narcotics. In addition to the issue of authority and institutional budgetary strength of the National Narcotics Agency, other technical issues in Indonesia's policy to deal with narcotics smuggling are the acceleration of the modus operandi of narcotics smuggling from abroad to Indonesia and the geographical factors of Southeast Asia.

\section{Law Enforcement in Malaysia}

In dealing with the circulation and smuggling of narcotics in Malaysia there are several institutions/institutions both from government and society. These institutions include PDRM, AADK, and also NGOs such as PEMADAM and Pengasih Malaysia. These institutions function in combating drug trafficking both by law enforcement and precautionary measures. This is certainly to achieve a drug-free situation for the country of Malaysia. The policy focus of the Malaysian Government is in drug trafficking and smuggling. The Malaysian government set up a special institution called the Malaysian National Anti-Dadah Agency which plays an important role in the trafficking and smuggling of narcotics. The norms and values of the ASEAN security regime are still focused on Malaysia's domestic national interests without further discussion regarding the circulation of narcotics in the Southeast Asia region where ASEAN values and norms have not yet been institutionalized in ASEAN member countries.

\section{Law Enforcement in Singapore}

In Singapore's own domestic country, the handling of narcotics using the institutional approach of Central Narcotics Bureau (CNB) which was established in 1971 is the main body responsible for implementing, coordinating the implementation of policies to deal with drug trafficking in each government agency. CNB itself is a separate body from the Republic of Singapore Policy. The CNB strategy focuses on efforts to reduce drug demand and production in Singapore. The efforts made by CNB in realizing Singapore that is clean of drugs can be in the form of arresting perpetrators and campaigns and education regarding the dangers of drugs to target groups of the community. The Singapore Narcotics Agency is focused on serving law enforcement in the narcotics field not to enter Singapore through smuggling activities. The norm of the ASEAN security regime in dealing with transnational crime in narcotics smuggling focuses on the declaration of ASEAN countries without entering into joint handling through ASEAN organizations as a legal entity to anticipate this. Although Singapore has agreed on the ASEAN Drug-Free declaration, the Singapore government also remains focused on protecting its citizens (national interest) from the danger of narcotics circulation. The Singapore government takes firm action against any violations that enter through the authority security checkpoint of Singapore officials.

\section{Law Enforcement in Brunei Darussalam}

In handling the transnational crime of narcotics smuggling in Brunei Darussalam, the Brunei Darussalam government formed a Narcotics Monitoring Bureau which was given the mandate to be responsible for all drug regulation and supervision through Article 27 of the Drug Abuse Act (Country Report of Brunei Darussalam, 2009). The Narcotics Control Bureau of Brunei Darussalam (NCB) which was established in 1988 and is a body under the Prime Minister carrying out its duties together with the Brunei Police and Anti-Narcotics Unit at the Ministry of Education. In its implementation Brunei Darussalam strongly supports the values and norms of the ASEAN security regime with the ASEAN Drug-Free declaration, but similar to other member countries, Brunei Darussalam is still focused on protecting its citizens from the threat of transnational narcotics smuggling using a persuasive approach to medical rehabilitation. Brunei Darussalam focuses on preventing drug smuggling by increasing supervision in the border region because Brunei Darussalam is one of the destination countries for narcotics smuggling. So that in joint prevention in the Southeast Asia region it is still not officially institutionalized at the ASEAN level and each member country is still focused on protecting its national interests.

\section{Law Enforcement in Thailand}

In handling transnational crime of drug trafficking in Southeast Asia and domestic Thailand, in 2003, the National Command Center for Combating Drugs (NCCD) was established. The NCCD is chaired by the Deputy Prime Minister, Gen. Meanwhile, the Secretary-General of the Narcotics Control Board serves as Secretary of the NCCD. The agency is tasked with continuing national campaign ideas on drug dealing. Meanwhile, for policies in terms of law enforcement carried out by FHs along with other law enforcement agents. In addition, the implementation of ASEAN Drug-Free requires Thailand not only to focus on overcoming and limiting narcotics and illegal drugs at the domestic level of the country but also at the ASEAN regional level. Therefore besides being carried out domestically the eradication of narcotics and illegal drugs carried out by Thailand also involves other ASEAN member countries as well as countries outside ASEAN. To optimize joint efforts in combating narcotics and illegal drugs in the face of ASEAN Drug-Free 2015, Thailand collaborates with several countries in the Southeast Asia region and outside the region. 


\section{Law Enforcement in Myanmar}

Narcotics prevention policies in Myanmar began to change during the reign of Thein Sein. Recognizing the potential threat posed by narcotics trading activities, Thein Sein's government redefined policies that were in accordance with the norms contained in the 2015 Drug-Free ASEAN to safeguard Myanmar's security and stability interests. Compliance with these norms is carried out not only because of binding rules, but Myanmar realizes that this is indeed appropriate. In the norms institutionalized in ASEAN Drug-Free 2015, ASEAN and other international organizations such as UNODC have a role as promoters of norms in the Southeast Asia region. Through international forums held, these international organizations persuasively advocate the internalization of norms for each member country. Based on the analysis of some of the policies above, it can be drawn a red thread that the drug policy promoted by Thein Sein has strong relevance to the policy recommendations from ACCORD, which in fact is a framework produced from the 2015 ASEAN Drug-Free norm. Therefore, these various policies can be considered as a form of Myanmar's support for the 2015 ASEAN Drug-Free regulation. The attitude is shown by Myanmar, both verbally and practically is a reflection of a country's compliance with the presence of regional norms. Guided by the norms and rules set out in the 2015 Drug-Free ASEAN, various changes were made by Myanmar as a form of self-actualization in carrying out actions that were in accordance with the standards of appropriate behavior. Thus, it can be concluded that the norms contained in the 2015 ASEAN Free Drug Declaration have influenced Myanmar policymakers in taking actions related to drug handling at the national level.

\section{Law Enforcement in Laos}

In overcoming the problem of narcotics in the Southeast Asia region, the Lao State government has formed the Lao National Commission for Drug Control and Supervision (LCDC). This body is a pioneer body to implement the Main Action Plan on Drug Control in Laos. The 2008 Lao Narcotics Act provides LCDC status as a body responsible for coordinating supervision and prevention which is also carried out by the Ministry of Public Security, Ministry of Foreign Affairs, Ministry of Finance, and other ministries related to the supervision and prevention of drug trafficking. Implementation of ASEAN Drug-Free, the Lao Government began to show compliance with the values and norms of the ASEAN security regime by changing the attitude of the Laos Government which was initially closed and repressive in enforcing regulations into an open policy and coordinating with other countries. Laos also collaborated with China and Thailand along with the inauguration of R3A.

\section{Law Enforcement in Cambodia}

The policy used by the Cambodian Government in dealing with transnational crime in drug trafficking in Southeast Asia in the context of the implementation of the ASEAN Drug-Free is to form the Cambodian National Police (CNP) which is tasked with enforcing the law regarding drug problems in Cambodia. Policies formulated by the Cambodian government and made legislation by the Cambodian Legislative Council, and implemented directly by CNP. The Cambodian government since 2014 has formed two units of a special unit of local domestic narcotics law enforcement officers and border areas that examine the circulation of narcotics that will enter or transit in Cambodia. The Government of Cambodia is also known as the Government regime which is quite closed to international problems. However, specifically, the problem of the threat of narcotics hazards in Southeast Asia including in Cambodia makes the Cambodian Government take an active role and show compliance with the ASEAN security regime, especially in the ASEAN Drug-Free. The Cambodian government ratified international agreements related to coordination in the handling of narcotics even though the problems of the selfishness of each government were still quite apparent especially in terms of handling narcotics which tend to be carried out to safeguard their respective national interests without further discussing maintaining Southeast Asian regional stability from the threat of narcotics smuggling.

\section{Law Enforcement in Filipina}

Law enforcement agencies in the Philippines that are in charge of dealing with transnational narcotics crimes in the Southeast Asia region are the Dangerous Drugs Board (DDB) and the Philippine Narcotics Agency (Philippine Drug Enforcement Agency or PDEA). Since the reign of President Rodrigo Duterte, the attitude of the Philippine government has been strong enough against the perpetrators of drug trafficking crimes. In addition to the death penalty for the perpetrators of narcotics crimes, President Duterte also gave instructions to the National Police and Narcotics Unit to give the police the right to be shot in place to perpetrators of narcotics crimes who tried to fight the legal apparatus. The Philippine policy in dealing with the transnational crime of drug trafficking by using the death penalty, on the one hand, is indeed effective in overcoming the rate of drug trafficking in the Philippines. However, the Philippine government's policy is considered to be less in accordance with the values and norms as well as the spirit of the ASEAN Drug-Free declaration. One of the work instructions of the ASEAN Drug-Free is the process of equating the views and policies of countries in dealing with narcotics smuggling in the Southeast Asia region by changing the repressive paradigm using a persuasive approach and public welfare. However, starting in 2015, the Philippine government under the leadership of President Duterte carried out a policy of capital punishment or "firing on the spot" against drug dealers and drug addicts without trial. So that this has become a problem in the compliance of the Philippines with respect to the values and norms of the ASEAN security regime in dealing with the transnational crime of drug trafficking in the Southeast Asia region. 


\section{Law Enforcement in Vietnam}

In handling transnational narcotics crimes in the Southeast Asian region, especially those entering Vietnam, the agencies in charge are the Vietnam police, the Armed Forces at the Vietnam Border, and Vietnam Maritime Police to become the main agents in the implementation of criminal policies, especially in the field of law enforcement. The policy formulated by the government and finally regulated by the Legislative Council became the role model of these agents. In carrying out its duties, the Vietnam Police cooperates with police from other countries and joins ASEANAPOL. In the framework of implementing the ASEAN Drug-Free Declaration, the Vietnamese government can also be categorized as a country that shows compliance with the values and norms of the ASEAN security regime, especially in dealing with transnational narcotics smuggling crimes. This can be seen from the similarity of the views of the Vietnamese government with other ASEAN countries, especially related to the rule of law. However, other problems arising from monitoring activities against Vietnam's compliance in the ASEAN security regime are in Vietnam's policies which are still based on the old perspective on the handling of narcotics in repressive ways without carrying out policy reforms that are based on aspects of community welfare. Based on the explanation of the problems of the negotiation process and the rule of law at the level of each ASEAN country, the problems of self-employment carried out by the ASEAN member governments are still not optimal so regional cooperation is needed in dealing with the crime of narcotics smuggling in the Southeast Asia region. But in addition to the above factors, there are still other supporting factors that have resulted in the ASEAN security regime not being optimal in dealing with transnational narcotics smuggling crimes in the Southeast Asia region.

\section{CONCLUSION}

The conclusion should be written in very clear words. It should explain how the objectives of the study accomplish the construction of values and norms agreed upon by ASEAN in the 2015 Declaration of ASEAN Drug-Free until now it has not been able to suppress the use and smuggling of narcotics in the Southeast Asia region. But on the contrary, in 2016 drug users and addicts in the Southeast Asia region are increasing due to changes and renewal of narcotics types, business benefits obtained by narcotics rubber lords and drug trafficking routes in the Southeast Asian region are changing and increasingly technologically sophisticated so that resulting in ASEAN countries not being able to follow the acceleration of the motives of perpetrators of narcotics smuggling crimes in the Southeast Asia region. Although there has been a real form of policy, in the implementation of narcotics handling policies in the Southeast Asia region which are still only focused on efforts to anticipate the partial and domestic nature of each country, the country is the most strict and strong in conducting operations against narcotics smuggling. Resulting in the country being able to handle transnational crime in drug trafficking in the Southeast Asia region. Besides that, the institutionalization of values and norms against the common threat related to narcotics has resulted in this focus still on which countries have the most negative impact of narcotics threats.

So that in the implementation of joint handling efforts for transnational narcotics smuggling crimes are still partial and have not been able to optimally touch the role of ASEAN as a joint community in dealing with transnational narcotics smuggling crimes in the Southeast Asia region. Based on the conclusions on the problems of ASEAN which are still not able to optimally handle the transnational crime of drug trafficking in the Southeast Asia region, several recommendations in this study are:

1. It is necessary to internalize the values and norms of the joint ASEAN declaration related to narcotics by all ASEAN heads of state and be reduced in the form of real policies that form the same throughout ASEAN member countries so that the declaration is not merely a ceremonial agreement.

2. There is a need for a humanitarian approach carried out by the ASEAN security regime through campaign activities, socialization, and persuasive approaches, especially among the younger generation so that mutual understanding between the children of the younger generation of ASEAN can be built on the dangers of narcotics threats. Some forms of policy that can be done are ASEAN youth activities, camps with school representatives of ASEAN member countries related to the dangers of narcotics so that children will be provided with an understanding and knowledge of the dangers of narcotics threats early on.

The establishment of an "ASEAN Narcotics Agency" (BNA) is needed which focuses on having the main tasks and functions like law enforcement agencies and has the same rights as the National Narcotics Agency in each ASEAN member country and members of the ASEAN Narcotics Agency. Nationally all ASEAN member countries so that with the existence of special institutions dealing with narcotics problems at the regional level, it is expected to be able to carry out their functions in anticipating narcotics smuggling at the ASEAN regional level so that the authors provide a concept of "Regional Integration Institutionalization" bridge in the implementation of negotiations at the national and regional levels.

\section{IMPLICATIONS}

The findings of the study implicate the development of international relations on the importance of narcotic transnational crime studies related to the dynamics of regional Southeast Asian organizations for the anticipation of drug circulation and illegal drugs. Furthermore, it is hoped to become a theoretical and practical recommendation in analyzing against the 
policy formulation of the ASEAN security regime organization and for the community to be an overview of the conditions and developments of transnational crime in the Southeast Asia region that has an impact on community security.

\section{LIMITATION AND STUDY FORWARD}

Limited research is conducted with a descriptive approach with data collection in ASEAN narcotics institutions and a more dominant view in circulation in Indonesia. So, the researchers can then conduct a deeper study of state perception that has not consistently run an agreement in the ASEAN region in the enforcement of narcotics smuggling.

\section{ACKNOWLEDGMENT}

The author thanked the UN organization who agreed to the anti-Narcotics Cooperation forum such as UNODC and countries outside Southeast Asia which helped a lot in this research and BNN Indonesia.

\section{AUTHORS CONTRIBUTION}

The first author in this article contributes to data collection and analysis of research data and is responsible for the findings of the article. The second researcher in this article contributes to the review literature and the study concepts in this article while the third author contributes to determining the methods in determining the type up to the analysis of research data.

\section{REFERENCES}

1. Fredy B. L. tobing (2002). Activity of Drugs Trafficking as a security issue that threatens state stability. international political Journals, 5(1).

2. Bambang Cipto (2007). Hubungan Internasional di Asia Tenggara "Teropong Terhadap Dinamika, Kondisi Riil dan Masa Depan. Yogyakarta: Pustaka Pelajar. Hal. 228.

3. UNODC (2016). United Nations Office on Drugs World Drug and Crime Report 2016.

4. Asean Narco Center (2016). The ONCB Hosted the senior Official and Ministerial Meeting on DrugsControl Cooperations Among Cambodia, Laos dan Thailand on 14-15Desember 2016 in Ubon Ratchathani Province.

5. Othman, Z., \& Idris, N. A (2016). Illicit drugs as a human security threat in East Asia. InS.Wajjwalku, London: Taylor \& Francis Ltd.

6. Gilligan, Philip and Shamim Akhtar (2006). Cultural Barriers to the Disclosure of Child Sexual Abuse in Asian Communities: Listening to What Women Say.The British Journal of Social Work, 36 (8), 13611377. https://doi.org/10.1093/bjsw/bch309

7. Inglehart, Ronald (1970). Public Opinion and Regional Integration. Journal International Organization, 24 (4) 764-795. https://doi.org/10.1017/S0020818300017525

8. Capie, David (2008). Localization as Resistance: The Contested Diffusion of Small Arms Norms in Southeast Asia. Journal Of Security Dialogue. 39 (6). https://doi.org/10.1177/0967010608098213

9. Kaseda, Y. (2012). Japan's security policy toward East Asia. Perceptions: Journal of International Affairs, 17(4), 27-48. https://dergipark.org.tr/en/pub/perception/issue/48981/624965

10. Coyne, J. W., \& Bell, P. (2011). The role of strategic intelligence in anticipating transnational organized crime: A literary review. International Journal of Law, Crime and Justice, 39(1), 60-78. https://doi.org/10.1016/j.ijlcj.2011.02.003

11. Jo, H., \& Simmons, B. A. (2016). Can the International Criminal Court Deter Atrocity?. International Organization, 70(3), 443-475. https://doi.org/10.1017/S0020818316000114

12. Alter, K. J., Hafner-Burton, E. M., \& Helfer, L. R. (2019). Theorizing the Judicialization of International Relations. International Studies Quarterly, 63(3), 449-463. https://doi.org/10.1093/isq/sqz019

13. Groupe de la Banque Mondiale. (2017). World development report 2017: Governance and the law. World Bank Group.

14. Ferejohn, J. (2002). Judicializing Politics, Politicizing Law. Law and Contemporary Problems, 65(3), 41. https://doi.org/10.2307/1192402

15. Friedman, E. (1996). Redrawing the line. The Healthcare Forum Journal, 39(5), 11-14. https://doi.org/10.1097/00004045-199601000-00007

16. McLlroy, D. (1992). The Social Impact. In IEEE Annals of the History of Computing (Vol. 14). https://doi.org/10.1109/85.150022

17. Ahmad, Z. H., \& Ghoshal, B. (1999). The political future of ASEAN after the Asian crisis. International Affairs, 75(4), 759-778. https://doi.org/10.1111/1468-2346.00107

18. Martínez, J. C., \& Eng, B. (2018). Stifling stateness: The Assad regime's campaign against rebel governance. Security Dialogue, 49(4), 235-253. https://doi.org/10.1177/0967010618768622

19. Srikanth, H. (2016). Combating Transnational Crimes in the Era of Globalization. International Studies, 53(2), 91-104. https://doi.org/10.1177/0020881717728157

20. Shiraishi, T. (2006). Comment on "Global and Regional Geo-strategic Implications of China's Emergence." Asian Economic Policy Review, 1(1), 197-198. https://doi.org/10.1111/j.1748- 
3131.2006.00021.x

21. Henry, L. (2007). The ASEAN way and community integration: Two different models of regionalism. European Law Journal, 13(6), 857-879. https://doi.org/10.1111/j.1468-0386.2007.00398.x

22. Jajri, I., \& Ismail, R. (2014). Determinants of migration from ASEAN-3 into Malaysia. Asian-Pacific Economic Literature, 28(2), 52-62. https://doi.org/10.1111/apel.12072

23. Hasenclever, A., Mayer, P., \&Rittberger, V. (1997). Theories of international regimes (Vol. 55). Cambridge university press.

24. Hasenclever, A., Mayer, P., \&Rittberger, V. (2000). Integrating theories of international regimes. Review of international studies, 26(1), 3-33. https://doi.org/10.1017/S0260210500000036

25. Sujianto, Syofian, \&Ikhsan (2018). Model Of Economic Development Collaborative Indigenous Peoples (Akit) Based On Social Capital In Enhancing Regional Competitiveness. Humanities \& Social Sciences Reviews,6(3),61-65. https://doi.org/10.18510/hssr.2018.639

26. Newman, E. (2001). Human security and constructivism. International Studies Perspectives, 2(3), 239251. https://doi.org/10.1111/1528-3577.00055

27. Jobes, P. C. (2003). Globalization and regional renewal revisited. Australian Journal of Social Issues, 38(1), 73-80. https://doi.org/10.1002/j.1839-4655.2003.tb01136.x

28. Kraft, H. J. S. (2017). Great Power Dynamics and the Waning of ASEAN Centrality in Regional Security. Asian Politics and Policy, 9(4), 597-612. https://doi.org/10.1111/aspp.12350

29. Kim, M. Hyung. (2014). Integration theory and ASEAN integration. Pacific Focus, 29(3), 374-394. https://doi.org/10.1111/pafo.12035 